Hutchison, A. \& Sibanda, N. (2017). A living customary law of commercial contradicting in South Africa: some law-related hypotheses.

South African Journal on Human Rights, 33(3): 380 - 405. http://dx.doi.org/10.1080/02587203.2017.1392430

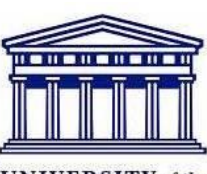

UNIVERSITY of the WESTERN CAPE

\title{
A living customary law of commercial contracting in South Africa: some law-related hypotheses
}

\author{
Andrew Hutchison and Nkanyiso Sibanda
}

\begin{abstract}
Inspired by calls to 'decolonise' South African law and legal education, this paper will posit some hypotheses as to the nature of a living customary law of commercial contracting from the perspectives of two South African contract law teachers. An account of the commercial format of customary contracting is largely absent from the law reports and leading legal textbooks in this country. The dominant narrative in existing legal sources, however, (which may be stereotyped), is of African communalism prevailing in customary contract practice. This is reflected, for example, in the discourse on 'ubuntu', which is being used at present as a vehicle for the constitutional transformation of the South African common law of contract. Other existing empirical accounts from discourses such as economics and anthropology also suggest, however, that contracting in indigenous African communities rests on notions of trust and community. This is reinforced by the existence of informal township dispute resolution structures. We will thus posit a central hypothesis that customary commercial contracting is relational in nature, using an inter-disciplinary literature review and drawing on the lived experiences of the authors. Other related hypotheses will also be developed. Ultimate truth here is a matter for future empirical study.
\end{abstract}

\section{Introduction}

Calls for 'decolonisation' of (contract) law and (contract) legal education in South African universities present a bit of a conundrum to us as local contract teachers. ${ }^{1}$ In this country, decolonisation, in the technical sense of throwing off the yoke of a foreign colonial power, happened decades ago. ${ }^{2}$ Of course, white minority rule only ended long after that, however, and racialized economic inequality remains a feature

\footnotetext{
1 This call has been firmly placed on the national higher education agenda by student protests occurring intermittently on most university campuses in South Africa since 2015. For an account of what the student protests were/are about, as well as the broader social and political context, the reader is referred to S Booysen (ed) Fees Must Fall: Student Revolt, Decolonisation and Governance in South Africa (2016).

${ }^{2}$ South Africa experienced Dutch colonialism from 1652 to 1795, whereafter it fell under English colonial power (except for a brief period between 1803 and 1806). Substantial independence was achieved by the ruling white authorities following the promulgation of the Statute of Westminster in 1931, however. In 1948, the newly elected nationalist government introduced a policy known as 'Apartheid'. This Apartheid government declared South Africa to be a fully independent republic in 1961 and left the British Commonwealth the same year under pressure from Britain. For accounts of South African legal history, see in particular R Zimmermann \& D Visser (eds) Southern Cross: Civil Law and Common Law in South Africa (1996); HR Hahlo \& Ellison Kahn The South African Legal System and its Background (1968) chapter 17; DH Van Zyl Geskiedenis van die Romeins-Hollandse Reg (1983) 476-503.
} 
of the South African landscape despite the emergence of a black middle class. ${ }^{3}$ Hence, 'decolonisation of law and the legal curriculum' as concepts used by our students must be taken to have a more figurative and symbolic meaning. Our intention here is not to engage the literature on decolonial theory, or to attempt a definition of 'decolonisation' as a concept to be applied in contemporary South Africa. Rather, our aim is to address a perceived epistemological gap in the African customary law discourse, namely the absence of an account of contemporary commercial practices by indigenous black South Africans. In our view and as we shall explain below, this gap arises from colonial policies, particularly surrounding issues of choice of law and African legal capacity. Our inquiry, based on an inter-disciplinary literature review, will rather propose a theoretical basis for a new line of African customary law inquiry.

As scholars in a discourse which is framed largely by historical and comparative scholarship on contracting, often grounded in European 'parent' legal systems, one could perhaps be forgiven for not having before pondered the issue of what is 'African' about contracting in South Africa, since this is not a topic traditionally covered in university legal education, or indeed in the academic discourse on contracts. Indeed, when one finally wakes up and demands an answer to this question, it is remarkably difficult to dig up appropriate study materials. Progressive private law is largely concerned at present with how to 'constitutionalise' the common law; while African customary law remains for the most part confined to the traditional 'ghettos' of family law, the law of succession, traditional leadership, and land rights. 4 What about commercial transactions? What is the governing legal regime for stokvels, burial societies, loan sharks (mashonisa), reciprocal loans between friends and family, or sales of immovable property in our informal settlements? Most would probably immediately refer to the 'law on the books', including specific pieces of legislation and indeed the residual common law of contract. Such a response would no doubt add that there is in fact only one system of South African law and that is law under the Constitution. 5 While this is possibly true, at least in a formal, positivist sense, what about in the de facto sense ('law in action')? And, where does that leave the theory of law known as legal pluralism, which has adherents all around the world, including most customary lawyers in South Africa, who have probably been thinking all along: what is the living African customary law of commercial contracting in South Africa?6

\footnotetext{
3 The transition to fully democratic government under the African National Congress commenced formally on 27 April 1994 . For an economic history of Apartheid South Africa, followed by an analysis of inequality in contemporary post-Apartheid South African society, see J Seekings \& N Nattrass Class, Race and Inequality in South Africa (2005). For a discussion of the relationship between law and poverty, see J Modiri 'Law's Poverty' 2015 (18) PELJ 224.

${ }^{4}$ Compare on African customary law, the leading texts of C Himonga \& T Nhlapo (eds) African Customary Law in South Africa: PostApartheid and Living Law Perspectives (2014); and TW Bennett Customary Law in South Africa (2004).

${ }^{5}$ Pharmaceutical Manufacturers Association of SA and Another: In re ex parte President of the Republic of South Africa and Others 2000 (2) SA 674 (CC), para 44; Bato Star Fishing (Pty) Ltd v Minister of Environmental Affairs and Tourism and Others 2004 (4) SA 490 (CC), para 22.

${ }^{6}$ Himonga \& Nhlapo (note 4 above) define 'legal pluralism' at 45. See further: TW Bennett, 'African Customary Law' in M Reimann \& R Zimmermann (eds) Oxford Handbook of Comparative Law (2006) 641, 666-671. For discussion of the concept of 'living customary law' in particular, see: TW Bennett 'Official' v 'Living' Customary Law: Dilemmas of Description and Recognition' in A Claassens \& B Cousins (eds) Land, Power, Custom (2008) 138.
} 
In this country, our Constitution holds that we are a legally plural system.7 This form of State-law pluralism, with an officially recognised African customary law which applies 'when applicable', ${ }^{8}$ should be distinguished from 'deep' legal pluralism which describes the pluralism phenomenon in a broader sense, namely the fact that de facto 'semiautonomous social fields'9 exist, which create binding normative systems for their relevant communities. ${ }^{10}$ This type of normative system, growing from the people upwards, rather than from the state downwards, is largely what will be described when we introduce our target context of the 'popular' economy. This allows us to look beyond the existing African customary law discourse to new social science sources for inspiration.

In this article, we the present authors, two South African-educated contract lawyers with an interest in (inter alia) legal theory, legal history, legal and economic anthropology, the constitutionalisation of contract law, and the future of African customary law, would like to posit some hypotheses about what a living customary law of commercial contracting in South Africa might look like. Of course, a reader may protest that a concept of a living customary law of any kind should only be put forward after extensive empirical research. This, we acknowledge is true. For now, our method will be to draw on the work of others in establishing a context in which African customary commercial contracting could operate. Nkanyiso Sibanda, one half of the present authorship, has first-hand experience of his own ethnic strain of African customary law. In places we will use his lived experience to supplement our written sources as a form of anecdotal evidence arising from his participation in the Cape Town popular economy. Most of the details related using this method are fairly trite and are common knowledge in South African indigenous circles: we hope that the reader will excuse the resultant absence of referencing where this occurs. Where possible, we rely on published accounts.

This paper will proceed as follows: in part 2, we will briefly situate our study using prevailing contract and legal theories. In part 3 we will set out some of the relevant aspects of the established legal discourse on African customary law. First hereunder, we will address conceptual issues as to the nature of 'African' customary law. We will then move to the accounts of customary contracting by other writers on African customary law - our version will remain general, here, however, without describing specific transactions. ${ }^{11}$ We introduce the published material subject to the same proviso above that the African customary law scholar should be careful not to get trapped in the epistemological snare of relying on written accounts of African customary law as being sacrosanct. We use these materials merely as a textbook style illustration of

\footnotetext{
${ }^{7}$ See section 211(3) of the Constitution of the Republic of South Africa, 1996.

${ }^{8}$ Ibid.

${ }^{9}$ SF Moore 'Law and Social Change: The Semi-Autonomous Social Field as an Appropriate Field of Study' (1972-1973) 7 Law \& Society Review 719.

${ }^{10}$ On the difference between state-law or weak legal pluralism and deep or unofficial legal pluralism, see C Rautenbach \& JC Bekker Introduction to Legal Pluralism 4ed (2014) chapter 1.

${ }^{11}$ For specific types of traditional African customary law contracts, see: Himonga \& Nhlapo (note 4 above) $188-195$.
} 
some of the literature available and subject to the caution that what we may be representing is 'official' customary law. Using the same methodology, we will also discuss African customary law dispute resolution in a more traditional setting, since we feel that this is relevant to our theoretical claims which we will develop in what follows. In part 4, we will move our concept of African customary contracting out of the traditional narrative's milieu, into the so-called 'popular economy', an economic context described by South African social scientists and by which we intend to refer in this study to South Africa's urban townships. This popular economy will serve as a new narrative site for discussion of 'customary commercial contracting', for which we will rely on the previously published empirical studies of others. We will draw on such sources to posit some hypotheses about the nature of a (modern, urbanised) living customary law of commercial contracting. Part 5 will summarise our central hypotheses as introduced in the preceding parts. Part 6 will conclude.

A final caveat before we continue: the term 'African' is employed in this article subject to notional 'scare' quotation marks. We do not intend to generalise or to stereotype here. We are responding to calls for contract law and contract legal education to better speak to the 'African' context, as well as Constitutional Court dicta to this effect.12 We hope that we do not fall into the trap of setting up an African exceptionalism: rather we explicitly work from certain universal assumptions, particularly the economic laws of the market place and the commonality of personal and business needs in a commercial context. Indeed, it is in this regard we acknowledge that the previously stated business reasons may underlie much of the universality of contract laws around the world, which requires a normative response from us as to what the potential role of incorporation of a parallel system of African customary commercial contract law might be.

\section{Atheoryofcontracting}

\subsection{Contract, status and legal theory}

In an influential nineteenth century work, Maine posited that: 'the movement of the progressive societies has hitherto been a movement from Status to Contract.'13 What Maine argued was that in early societies, one's role and influence was largely shaped by one's membership of a traditional social grouping, particularly one's family. ${ }^{14}$ Maine's thesis was that as society progressed, parties achieved a greater measure of personal autonomy and were able to associate with one another and allocate resources by agreement, so that one might bargain for a better deal and improve one's status in society through contracting. 15 This theory fits in nicely with ideas like freedom of contract, laissez-faire economics, and (political) social contractarianism, which would

\footnotetext{
12 The clearest dictum to this effect is to be found in the minority judgment of Yacoob J in Everfresh Market Virginia (Pty) Ltd $\mathrm{v}$ Shoprite Checkers (Pty) Ltd 2012 (1) SA 256 (CC), para 23. See also: the majority judgment of Ncgobo J in Barkhuizen v Napier 2007 (5) SA 323 (CC), para 51; the majority judgment of Moseneke J in Everfresh, para 72. Compare the sentiment expressed by Madlanga J in Paulsen and Another v Slip Knot Investments 7772015 (3) SA 479 (CC), para 66.

${ }^{13}$ HS Maine Ancient Law cheap ed (1905 [1861]) 151.

${ }^{14}$ Ibid, see in particular chapter 5.

${ }^{15}$ Ibid 149-151. See also chapter 9.
} 
have characterised the British social context in which Maine wrote. ${ }^{16}$ Indeed, ideas such as the 'civilising mission of contract', much reviled in certain modern circles, could be thrown in here. ${ }^{17} \mathrm{~A}$ movement towards a monetised economy and wage labour, and away from hereditary social hierarchies underpin this type of philosophy. It also works well in conjunction with a liberal free-market economy and prevailing (contemporary British) notions of capitalism.

What the 'status to contract' progression does not account for, however, is the social nature of humans, particularly with regard to contracting. Although first discussed as a theory of contracting over a century after Maine wrote, relational contract theory has demonstrated the ever-present significance of human relations and networks in contracting, particularly in repeated or ongoing transactions. ${ }^{18}$ There is a strong inter-personal element to business, which can manifest as co-operation as well as competition. Indeed, norms such as trust and reciprocity are as much a part of business as adversarialism and opportunism. Inter-personal relations are also among the reasons why negotiation remains the most prevalent form of dispute resolution in business, regardless of what the law of contract in a given location might be. ${ }^{19}$ To the extent that a given site for contracting is in a community (read: localised market) where the role players are known to each other, it is likely that contracting will adhere to the tenets of relational contract theory.

This is not to say, of course, that there is no element of individualism to contract practice. Writing from a United States point of view, Fried's argument that contracting is based on individual determinism and that issues of distributive justice are best left to the public law realms of taxation and welfare, hold water, at least in the setting of formal, liberal, Westernised contract law. ${ }^{20}$ What this theory rests on of course, are the dual notions of personal autonomy and private property. ${ }^{21}$ Much of the conventional narrative on 'African' social norms holds that 'African' society is

\footnotetext{
${ }^{16}$ PS Atiyah The Rise and Fall of Freedom of Contract (1979) part II describes the period of British history between 1770 and 1870 as 'the age of freedom of contract'. Atiyah's history of the concept of freedom of contract (and related philosophical and economic trends) ends at the time of writing (the late 1970s), where he reflects that the 'wheel had come full circle' and that freedom of contract as a concept had 'fallen' in his contemporary British epoch. In this conclusive chapter 22 (at 716) he makes the observation that in his contemporary Britain, there had been a 'reversion from 'contract' to 'status", citing Maine. While the British political economy was to take a turn to the right shortly thereafter, this observation by Atiyah is an interesting one. Indeed it is useful exercise to similarly reflect on the contract/status theme in our own contemporary South Africa: the conclusion in part 6 below will return to this theme.

${ }^{17}$ For critical discussion with reference to the literature, see: A Supiot Homo Juridicus: On the Anthropological Function of the Law (2007) 79-86; L Siliquini-Cinelli 'Reflections on the Pactum in the Public and Private Spheres' in L Siliquini-Cinelli \& A Hutchison (eds) The Constitutional Dimension of Contract Law: A Comparative Perspective (2017) 289. In South Africa, this terminology is linked with colonialism, rather than liberalism per se, see for example: Himonga \& Nhlapo (note 4 above) 6.

${ }^{18}$ For the seminal texts, see (for example): IR Macneil 'The Many Futures of Contracts' (1974) 47 Southern California LR 691; IR Macneil The New Social Contract: an Inquiry into Modern Contractual Relations (1980); S Macaulay 'Noncontractual Relations in Business - A Preliminary Study' (1963) 28 American Sociological Rev 55. For secondary discussion of relational contract theory, see for example: D Campbell (ed) The Relational Theory of Contract: Selected Works of Ian Macneil (2001); J Braucher, J Kidwell \& WC Whitford (eds) Revisiting the Contracts Scholarship of Stewart Macaulay (2013); D Campbell, L Mulcahy \& S Wheeler (eds) Changing Concepts of Contract: Essays in Honour of Ian Macneil (2016). For a different take on relational contract theory see: H Collins Regulating Contracts (1999).

${ }^{19}$ For contract sources, the seminal text is: Macaulay (note 18 above). From an alternative dispute resolution point of view, see: $\mathrm{R}$ Fisher, W Ury \& B Patton Getting to Yes: Negotiating an Agreement Without Giving In 3 ed (2012); J Brand, F Steadman \& C Todd Commercial Mediation: A User's Guide (2012) chapter 2.

${ }^{20} \mathrm{C}$ Fried Contract as Promise (1981).

${ }^{21} \mathrm{Ibid}$, see in particular the foundational chapter 2.
} 
more communal in nature than 'Western' society, and that the interests of the individual are often sub-ordinated to that of the group. ${ }^{22}$ Gyekye, a Ghanaian, describes how this type of argument was employed by post-colonial leaders in several African countries in order to found a system of government based on 'African socialism'.23 Gyekye and other African philosophers argue against this type of narrative: in their view, there is no opposition to individualism, or individual interests in most African cultures. ${ }^{24}$ One need not be entirely altruistic or selfless in one's behaviour. Rather, Gyekye convincingly puts forward a notion of 'moderate communitarianism', in which there is space for individual interests, provided these are tempered with social responsibility. ${ }^{25}$ This is a fascinating conception of the political economy, which resonates with, for example, the special protection given to socio-economic rights under the Constitution of the Republic of South Africa, 1996 ('the Constitution'). ${ }^{26}$ Gyekye's account leaves room for basic principles of autonomy and private property, which underlie liberal theories of contracting, such as Fried's. We submit, however, that Gyekye's moderate communitarianism is possibly closer to the South African model of a constitutionally circumscribed model of contracting, than to other systems (such as Fried's model) which recognise a greater role for freedom of contract.

For our account below, we do not wish to take issue with either contractual autonomy or private property, both of which are at the heart of most market-based systems of contract law, which would include South Africa. Our approach to contract theory will be from a different angle, focussing on the socially embedded nature of contractual relations and legal pluralism. We hope to provide a new South African angle on the status to contract claim: our view is that there is a strong relational element to all contracts, including customary ones (ie a 'status'); and that if one accepts legal pluralism theory, this status element is very much a part of contract law, especially in the modern South African customary context. Hence, status and contract exist contemporaneously and are both vital parts of modern customary commercial contracts.

\subsection{Legal pluralism and contracting in South Africa: existing texts}

Where then does one begin with a literature review to investigate the living African customary law of commercial contracting in South Africa? Existing signposts in written sources include the following:

\footnotetext{
${ }^{22}$ In South Africa, the literature on ubuntu refers: Mokgoro, 'Ubuntu and the Law in South Africa' (1998) 4 Buffalo Human Rights LR 15; D Cornell \& N Muvangua (eds), Ubuntu and the Law (2012); F Diedrich (ed) Ubuntu, Good Faith \& Equity: Flexible Legal Principles in Developing a Contemporary Jurisprudence (2011); H Keep \& R Midgley 'The Emerging Role of 'Ubuntu-Botho in Developing a Consensual South African Legal Culture' in F Bruisma \& D Nelken (eds), Explorations of Legal Cultures (Elsevier 2007) 29; C Himonga 'The Right to Health in an African Cultural Context: The Role of Ubuntu in the Realization of the Right to Health with Special Reference to South Africa' (2013) 57 J of African Law 165; L Praeg A Report on Ubuntu (2014).

${ }^{23}$ K Gyekye Tradition and Modernity: Philosophical Reflections on the Africa Experience (1997) chapter 5.

${ }^{24}$ Ibid, chapter 2. See further: DA Masolo Self and Community in a Changing World (2010) 245-250.

${ }^{25}$ Gyekye (note 23 above) chapter 2.

${ }^{26}$ For an Afrocentric defence of socio-economic rights in South Africa, see: Himonga (note 22 above).
} 
i.Textbook accounts of African customary law in South Africa; 27

ii.Judgments of South African courts, particularly the apex Constitutional Court, on contracting; 28 and

iii.Published empirical studies of the popular economy. ${ }^{29}$

Of these three possible avenues of inquiry, textbook accounts (category (i)) represent (in our view) a largely pre-commercial vision of society, which Himonga and Nhlapo warn may be a distorted and outdated picture. $3^{\circ}$ Indeed, we have our doubts about the methodology of presentation of certain accounts of African customary law, particularly those on contracting, since the terminology and categorical excursus is sometimes closely based on Roman law. We feel that this is a key epistemological error in African customary law analysis as it assimilates such customary law to the European discourse. Our view in this paper is that contracting, as a process, is indeed a universal cultural phenomenon based on consensual exchange, but that alien terminology should not be imposed on it. ${ }^{11}$ In our view, some accounts thus represent the material better than others. These traditional sources will nevertheless be discussed in the following part 3 .

Then, the dicta from the Constitutional Court (category (ii)) present a potentially idealised vision of society, which, at least in the cases dealing with contracts, is seldom backed up by empirical evidence, relying rather on a judge's own personal world view, or a nominally 'African' world-view. ${ }^{2}$ While the Constitutional Court's jurisprudence on contracting has demonstrated a desire to introduce greater fairness, and particularly distributive ('social') justice through transforming the common law, there has been very little attempt to develop a living customary law of contracting. (This is probably best explained, in a precedent based system, by a lack of appropriate cases.) A database search of South African case precedents from all levels of the judiciary and going back several decades also reveals little of use here. 33 We will not dwell too long on an analysis of the constitutional dimension of contract law in South Africa, or the concomitant notion of 'ubuntu'. This has been done elsewhere by ourselves and others. 34

\footnotetext{
${ }^{27}$ Himonga \& Nhlapo (note 4 above); TW Bennett (note 4 above); Rautenbach \& Bekker (note 10 above); JC Bekker 'Law of Contract' in WA Joubert (ed) The Law of South Africa Vol 32 'Indigenous Law' 2 ed (2009) paras 230-243.

${ }^{28}$ There is a growing list of these cases. In addition to the Barkhuizen, Everfresh and Paulsen cases cited in note 12 above, see in particular: Botha v Rich NO 2014 (4) SA 124 (CC); Makate v Vodacom Ltd 2016 (4) 121 (CC). Omitted here are several cases on specific consumer law regimes, such as residential leases and consumer credit.

${ }^{29}$ These sources will be discussed in part 4 below.

${ }^{30}$ Himonga \& Nhlapo (note 4 above) 195, citing RB Mqeke Customary Law and the New Millenium (2003) 118.

${ }^{31}$ Our view is of course an opinion, rather than an empirically proven fact. We simply intend to draw attention to the idea that contracts, in the sense of obligations created by agreement, are likely to be found in any grouping of people who are not individually selfsufficient. We argue further that contracting is the basis of any sort of business, and that a concept of agreements which are viewed as being normatively binding is fundamental to such business and is hence universal in that sense.

${ }^{32}$ Compare the passages cited in note 12 above.

${ }^{33}$ There are exceptions, see for example: Mndi v Malgas 2006 (2) SA 182 (EPD), a case concerning a stokvel.

${ }^{34}$ For leading views of South African scholars on the constitutionalisation of contract law, see (ex pluribus): D Bhana 'The Role of Judicial Method in Contract Revisited (2015) 132 SALJ 122; M Wallis 'Commercial Certainty and Constitutionalism: Are They Compatible' (2016) 133 SALJ 545; DM Davis \& K Klare 'Transformative Constitutionalism and the Common and Customary Law' (2010) 26 SAJHR 403; J Barnard-Naud_e 'Of Dorothy's Dog, 'Poststructural' Fairy Tales ... and the Real: Power, Poverty and the General Principles of the South African Law of Contract' (2013) 29 SAJHR 469; FDJ Brand, 'The role of good faith, equity and fairness
} 
Avenue (iii) presents potentially the most productive avenue of inquiry, although the material here is largely not the work of lawyers, but rather economic anthropologists and economic sociologists. It is from category (iii) empirical studies that the most can be learned (in our view) about how indigenous African people who may today reside in urban settings, but who still choose to observe certain African customary law practices, go about the business of commercial contracting. 35 This context will be set out in part 4. The result will be a set of hypotheses about the living customary law of commercial contracting in South Africa from which to work in possible future empirical studies.

Of course, we also require a reason for this perceived gap in the representation of African customary law. We believe that there are historical reasons for this, particularly in the South African context of a prior system of white minority rule and black sub-ordination and disenfranchisement. A useful source for this type of argument would be Chanock's alternative history of the formative early twentieth century period of South African law and society. ${ }^{36}$ Chanock argues that South African law was systematically segregated during this period into one branch ('common law A'), which served the needs of the white population (here, of course, we mean the Roman Dutch/English law mixture); and another branch ('common law B') which served the African population (African customary law, but as applied and distorted by white government officials). ${ }^{37}$ Supervening on these two systems of law were choice of law rules which favoured 'common law A' in most commercial types of contract, particularly where one of the parties was white, or a white-owned juristic person. $3^{8}$ This led to the side-lining of the development of a 'common law B' of commercial contracting - leaving this branch of the law to operate largely in a familial setting. 39 Central to Chanock's argument is that this process was not about (contract) law at all, but rather about race and specifically African capacity to partake in the South African economy. $4^{\circ}$ We will argue in what follows that this does not mean that there is no such thing as an African customary commercial contract law; Chanock's history does, however, suggest why there is no 'official' version of this branch of the law. Whether the future of contract law in South Africa should hold a reconciliation of 'common law A' and 'common law B', including in the law of contract, is a question to which we will return in our concluding part 4. De facto, two parallel systems of law continue to operate - this is unlikely to change with regard to a 'living' 'common law B' (particularly from the point of view of deep legal pluralism) - but some form of future synthesis

in the South African law of contract: A Further Instalment' (2016) 27 Stell LR 238; C Lewis, 'The uneven journey to uncertainty in contract' 2013 (76) THRHR 80.

For Andrew Hutchison's views on constitutional/contract law, see (for example): Alistair Price \& Andrew Hutchison 'Judicial review of exercises of contractual power: South Africa's divergence from the common law tradition' (2015) 79 Rabels Z 822; A Hutchison 'Decolonisation of South African contract law: an argument for synthesis' in Siliquini-Cinelli \& Hutchison (eds) The Constitutional Dimension of Contract Law: A Comparative Analysis (Springer, 2017) 151.

${ }^{35}$ Indigenous African people who reside in South African urban areas have a unique mode of social ordering, which has resulted in them observing African customary law in a manner which takes into cognisance the needs of urban life. See part 4.2 below for further details.

${ }^{36}$ M Chanock The Making of South African Legal Culture 1902-1936: Fear, Favour and Prejudice (2001).

${ }^{37}$ Ibid, this is the central narrative throughout the book.

${ }^{38} \mathrm{Ibid}$, again this is central. See in particular part IV, especially chapters 13 and 14.

${ }^{39}$ Ibid.

${ }^{40} \mathrm{Ibid}$, see in particular the discussion of the ownership of land in South Africa in chapter 15. 
may be an option for 'common law A', with implications for the law of commercial contracting in South Africa generally. ${ }^{41}$

\section{The traditional African customary law of contracting}

In what follows we will set out a largely textbook account of African customary law, African customary contracting, and African customary dispute resolution, as captured in the South African legal discourse. This material may be familiar to those with an interest in African customary law, and some of it would be covered in standard LLB courses on this subject in South African universities. We will give a summary of these topics nevertheless, in the interests of presenting a balanced literature review of the available material and in order to contextualise the reader who has a low level of familiarity with textbook accounts of African customary law. We also set up this representation, which we will call the 'traditional' account, in order to juxtapose it with an edgier social science account of commercial contracting in the popular economy' of South Africa's urban townships in the following part 4.

\subsection{A working definition of African customary law}

Many writers have already dealt with the challenges related to having one universally acceptable definition of African customary law, so we will not repeat this material.42 For our purposes, it will, however, be helpful to propose a working definition of African customary law against which our hypotheses may be tested.

Initial definitions of 'African customary law' explained this concept as those norms and practices which only applied to members of a particular cultural group to the exclusion of others. Hamnett, for example, viewed African customary law as 'a set of norms which the actors in a social situation abstract from practice and which they invest with binding authority'. ${ }^{43} 43$ Jobodwana, by contrast, stressed the importance of 'customs and traditions' which work to regulate the way community members live44. In an analogous context, Bennett described African customary law as deriving 'from social practices that the community concerned accepts as obligatory.' 45

Various pieces of legislation offer additional definitions of African customary law: for example, the Law of Evidence Amendment Act 46 ('LEAA') gave the first statutory definition of African customary law in South Africa. At section 1(4), the LEAA defined African customary law as the law or custom as applied by the Black tribes in the

\footnotetext{
${ }^{41}$ For argument to this effect, see Hutchison (note 34 above - 2017).

${ }^{42}$ See for example: ZN Jobodwana 'Customary Courts and Human Rights; Comparative African Perspectives' (2000) 15 SA Public Law 26, 30-33; Bennett (note 4 above) chapter 1; TW Bennett A Sourcebook of African Customary Law for Southern Africa (1991) chapter 1; C Himonga \& C Bosch 'The application of African Customary Law under the Constitution of South Africa: Problems solved or just beginning?' (2000) 117 SALJ 306; I Hamnett Chieftainship and Legitimacy: An anthropological study of executive law in Lesotho (1975) chapter 1; TW Bennett 'Re-introducing African customary law to the South African legal system' (2009) 57 American J of Comparative Law 1; V Bronstein 'Reconceptualising the customary law debate in South Africa' (1998) 14 SAJHR 388.

${ }^{43}$ Hamnett (note 42 above) 14.

44 Jobodwana (note 42 above) 30.

${ }^{45}$ Bennett (note 4 above) 1; see also Bennett (note 6 above) 138.

${ }^{46}$ Act 45 of 1988 .
} 
Republic'. In 1998, a new definition of African customary law was introduced by the South African Law Reform Commission, 47 which was also later incorporated into the Recognition of Customary Marriages Act, 48 as well as the Reform of Customary Law of Succession and Regulation of Related Matters Act.49 This definition refers to African customary law as 'the customs and usages traditionally observed among the indigenous African peoples of South Africa and which form part of the culture of those peoples.'50

While various definitions of African customary law have thus been suggested, these all share common definitional attributes, which feature assists in bringing some consensus to what the concept of African customary law in South Africa entails. A working definition therefore would thus rest on two notions: first, that such law consists of customs and usages that are traditionally observed by a community of indigenous African people of South Africa; and secondly, there must be a claim that these practices form part of the culture of those people and hence have normative force. It is important that these customs should be widely accepted and acknowledged by a traditional indigenous group. ${ }^{51}$ According to Bennett, rules that are not acknowledged by people or that are dictated by outsiders as African customary law are invalid. $5^{2}$ To this effect, Jobodwana reiterates that it is important for a traditional community's members to actually accept the body of rules as binding on themselves. 53

There are two forms of African customary law that co-exist and are acknowledged in South Africa: 'living' customary law and 'official' customary law.54

Living customary law consists of the actual rules and practices which govern the indigenous people whose law is being considered. .555 It comprises unwritten practices that regulate the day-to-day lives of a traditional community or a person who belongs to such a community. These social practices, however, are continually changing in accordance with the evolving practices of the community..$^{6}$ Bekker and Rautenbach echo this sentiment, arguing that an important attribute of living customary law is its

\footnotetext{
${ }^{47}$ See: South African Law Commission Project 90: Report on customary marriages (1998) 43.

${ }^{48}$ Act 120 of 1998.

49 Act 11 of 2009.

${ }^{50}$ See the definition of 'customary law' provided in section 1 of both Acts.

${ }^{51}$ In Van Breda v Jacobs 1921 AD 330, the court held that for a custom to be acknowledged in law, it must meet four requirements, namely: it must be long established; reasonable, uniformly observed; and certain. Himonga \& Nhlapo (note 4 above) 30-31 distinguish, however, the nature of living customary law from the Roman Dutch concept of custom. Nevertheless, in Shilubana v Nwamitwa, 2007 (2) SA 432 (SCA), the court reiterated the fact that for a practice to be regarded as a custom, it should have been observed immemorially.

52 Bennett (note 6 above) 138.

53 Jobodwana (note 42 above) 30.

54 The co-existence of these two types of customary laws has been acknowledged by the courts. See for example Mabena v Letsoalo 1998 (2) SA 1074 (T); Ramuhovhi and Another v President of the Republic of South Africa and Others 2016 (6) SA 210 (LT); Shilubana (note 51 above); Makholiso and Others v Makholiso and Others 1997 (4) SA 509 (TkS).

${ }^{55}$ Himonga \& Nhlapo (note 4 above) 26.

${ }^{56}$ See also Ramuhovhi (note 54 above) para 51 where the court held that the very nature of African customary law is that it is 'a dynamic, evolving system of values, inherently flexible, and which is practised in a specific community'. In the context of African
} 
perpetual adaptation to the evolution of a community: it is not static. 57 Commenting on the changing nature of living customary law, Bennett wrote:

Systems of custom therefore have the remarkable ability to allow forgotten rules to sink into oblivion, while simultaneously accepting new rules to take their place, always on the understanding that the new is old. 58

This dynamic characteristic of living customary law has also been acknowledged by the courts: for example, the majority judgment in Bhe $v$ Magistrate, Khayelitsha referred to living customary law as a 'dynamic system of law which is continually evolving to meet the changing circumstances of the community in which it operates'.59 In Alexkor, the Constitutional Court explained that living customary law refers to a set of traditional rules which have been in existence since time immemorial which have always changed and developed to address the needs of the relevant population. ${ }^{60}$ The Constitutional Court held further that this system of law would 'continue to evolve within the context of its values and norms consistently with the Constitution'.61 In similar fashion, the same court in Shilubana held that the very nature of living customary law is that it is not static but adaptative. 62

Living customary law is thus not stagnant; rather, it always recognises and acknowledges on-going changes amongst people who are bound by it and who adapt to such changes for the convenience of the community. This means that out-dated African customary law rules which are no longer being observed by the community are replaced by new ones, without the need for a formal process of amending the rules. A classic example of such a change is found in Shilubana. In this case, the Valoyi Royal Council changed the patriarchal principle of male primogeniture, ${ }_{6}{ }_{3} 63$ which allowed only males to succeed as King, and instead allowed a female to succeed to the throne in line with the equality provision in section 9 of the Constitution. The community's acceptance 64 of this change reflects a transformed notion of the African customary law principle of male primogeniture. 65

customary contracting, see: S Mancuso 'Trends on the Harmonization of Contract Law in Africa' (2007) 13 Annual Survey of International \& Comparative Law 157, 175.

57 JC Bekker \& C Rautenbach 'Nature and Sphere of African Customary Law' in Rautenbach \& Bekker (note 10 above) 29.

${ }^{58}$ Bennett (note 4 above) 2.

${ }^{59}$ Bhe and Others v Magistrate, Khayelitsha, and Others (Commission for Gender Equality as Amicus Curiae); Shibi v Sithole and Others; South African Human Rights Commission and Another v President of the Republic of South Africa and Another 2005 (1) SA 580 (CC), para 153.

${ }^{60}$ Alexkor Ltd and Another v Richtersveld Community and Others 2004 (5) SA 460 (CC), para 153.

${ }^{61}$ Ibid, para 153.

${ }^{62}$ Shilubana v Nwamitwa, (note 51 above), para 54; SALC Project 90 (note 47 above), para 2. 3. 2; TR Nhlapo 'The African Family and Women's Rights: Friends or Foes' (1991) Acta Juridica 135.

${ }^{63}$ Madolo v Nomawu (1896) 1 NAC 12; Makholiso and Others v Makholiso and Others 1997 (4) SA 509 (TkS), 519E. See also AJ Kerr The Customary Law of Immovable Property and of Succession 2 ed (1990) 99.

${ }^{64}$ See Shilubana (note 51 above), para 54, where the Court noted that the 'Valoyi people moved away from any previously existing rule that a woman could never be appointed as a Hosi'. Of course the acceptance was not unanimous, there were dissenting voices.

${ }^{65}$ Another example that illustrates the fluidity of living customary law is found in Mabena v Letsoalo (note 54 above) where it became acceptable for a female head to negotiate and accept lobolo, a role which had traditionally been always reserved for males. 
Official customary law, on the other hand, stands in direct contrast to living customary law in so far as it is written and hence crystallised and fixed at the time of writing. It is the law that is generally applied by the courts as well as other state institutions because it is easy to ascertain. ${ }^{66}$ It is written and codified, and is reflected in textbooks, judicial precedents, and other scholarly publications. ${ }^{67}$ Bennett refers to official customary law as 'ossified in official code' on account of this written nature. ${ }^{68}$ In Bhe, the court held that official customary law exists in textbooks as well as in statutes. ${ }^{69}$ Since the official law captures a living oral tradition in written form, it does not accurately reflect true African customary law.70 For this reason, the courts prefer to apply the living version of African customary law.71

\subsection{Traditional African customary contracting}

The textbook accounts of the African customary law of contract have significant differences from the prevailing common law of contract. Some examples of these differences would be: the types of agreements found within African customary law; the nature of the underlying transactions; the requirements for the formation of a contract; the nature of performance; and finally, the nature of contract enforcement and dispute resolution.72 By definition, a 'contract' entails agreement between parties: this type of transaction is also found in African customary law, usually for a performance (and hardly ever for non-performance), between two adult parties who reach the voluntary consensus that violation of their agreement's terms should result in legal consequences. African customary law contracts are generally concluded by a simple verbal agreement between parties. This by implication requires there to be at least one witness to a contract who will be able to give evidence about its existence in case of a dispute.73 A written document is uncommon. African customary contracts also do not necessarily follow a particular format.

The literature describes the socially embedded nature of African customary contracting, where authority for a particular party to unilaterally enter into a contract is limited. 74 This is because most contracts in African customary law affect the entire family or community: while some types of transactions are exempted,75 an individual is usually expected to consult with the rest of his or her family before he or she concludes a contract. The male family head usually contracts on behalf of his family, but he is generally expected to consult with the older (mostly male) members of this family before the conclusion of the contract. $7^{6} \mathrm{He}$ is also ultimately responsible for the

\footnotetext{
${ }^{66}$ Himonga \& Nhlapo (note 4 above) 33; Rautenbach \& Bekker (note 10 above) 29; Bhe (note 59 above), para 87.

${ }^{67}$ Rautenbach \& Bekker (note 10 above) 28.

${ }^{68}$ Bennett (note 4 above) 64.

${ }^{69}$ Bhe (note 59 above), para 86.

${ }^{70}$ Ibid.

${ }^{71}$ Ibid, paras 83-95.

${ }^{72}$ In this regard, see also Mancuso (note 56 above).

${ }^{73}$ Ibid 174.

${ }^{74}$ Ibid 174.

${ }^{75}$ For example: small transactions which do not have an impact on the contracting party's family. There are infinite examples of these everyday transactions such as (for instance) where one party asks for a cup-full of sugar in exchange for some maize porridge.

${ }^{76}$ Rautenbach \& Bekker (note 10 above) 145.
} 
fulfilment of the contract.77 Rautenbach and Bekker correctly point out that the extent of a contracting party's duty of consultation depends on the nature of the contract being entered into. ${ }^{8}$ Contracts which may affect the entire family will require more extensive consultation than less consequential contracts which may potentially affect only the individual.79

When it comes to contractual negotiations under African customary law, sources point towards legal representation of the parties being uncommon. ${ }^{80}$ In family-centric contracts such as marriage, however, uncles and aunts usually negotiate on behalf of the potential spouses as well as the broader family. ${ }^{81}$ These parties do not negotiate as authorised representatives (in a legal sense), but simply as intermediaries or mouthpieces who act for, and represent the interests of, the potential parties to a contract. ${ }^{82}$ In terms of transmissibility of contractual rights, some accounts of the law report that mechanisms which are the functional equivalents of the common law's delegation, cession or other related means of transferring the duties of one party to a third party, are generally uncommon in the African customary law of contract. 83 Contractual negotiations are described as being informal and there is usually no technical ritual performed in order to formally create obligations. Most contracting parties will have a good knowledge of the general principles of law involved and hence a legal representative is not required to intermediate between them.

\subsection{Traditional African customary dispute resolution and contracting}

Due to the socially embedded nature of customary contracting described above, performance under such contracts by the parties involved has personal implications for their broader families, with reputation, respect, and honour of the family name at stake. In the event of conflict, traditional communities have their own customary courts and dispute resolution mechanisms, which are deeply rooted in the customs and traditions of each particular group. These traditional platforms and mechanisms operate in a manner aimed at preventing violence, curbing the perpetuation of conflict, and the avoidance of damage to the relationship between the parties involved: all of which could ultimately threaten the social fabric. ${ }^{84}$

The lowest level of traditional court is the family court, which is usually presided over by the male head of the family. ${ }^{85}$ Should such proceedings fail, then the next forum

\footnotetext{
77 See: ibid 145; M Prinsloo \& L Vorster 'Parties' in Centre for Indigenous Law (ed) Indigenous Contract in Bophuthatswana (1990) 21.

${ }^{78}$ Rautenbach \& Bekker (note 10 above) 145.

${ }^{79}$ Ibid.

${ }^{80}$ Ibid.

${ }^{81}$ Ibid.

${ }^{82}$ Ibid.

${ }^{83}$ Ibid 146; Prinsloo \& Vorster (note 77 above) 25

${ }^{84}$ See also B Ingelaere 'The Gacaca Courts in Rwanda' in L Huyse \& M Salter (eds) Traditional Justice and Conflict Resolution After Violent Conflict: Learning From African Experiences (2008) 25, 33 available at: $<$ http://www.idea.int/sites/default/files/publications/traditional-justice-and-reconciliation-after-violent-conflict-learning-fromafricanexperiences_0.pdf >; M Cappelletti 'Access to justice as a theoretical approach to law and a practical programme for reform' (1992) 109 SALJ 22; TW Bennett A sourcebook of African customary law in Southern Africa (1991) 54.

${ }^{85}$ Himonga \& Nhlapo (note 4 above) 255-256; Bennett (note 4 above) 142.
} 
is a hearing before the extended families where the (mostly) male elders of the extended family deliberate on the matter under the guidance of the family patriarch. 86 The matter could thereafter be taken to the village head and from there ultimately to the Chief's court. 87 In some instances, communities have a Paramount Chief who provides the final level of the customary court authority. Chiefs are public officials who have jurisdiction to handle both civil and criminal matters. ${ }^{88}$ In the rare instances that the Chief's court fails to settle a dispute, the matter then progresses to the formal court system, beginning with the Magistrate's Court and from there following the usual hierarchy upwards. ${ }^{89}$

Traditional courts are largely informal institutions which do not have rigid rules of procedure. ${ }^{\circ 0}$ The presiding officials there usually have no formal training. There is no legal representation or recording of proceedings and the courts rely solely on the traditions and customs of the parties to the dispute. Where a matter has gone beyond the bounds of the family court, the entire community may become involved in resolving the dispute. ${ }^{11}$ On the day of the court hearing, for example, the community will gather at a designated place and the contending parties are then given the opportunity to present their cases. ${ }^{22}$ Each of the community members in attendance is allowed to examine any of the evidence presented by either of the litigants. 93 There is typically no specified order of examining or cross-examining the witnesses or parties to the dispute. 94 The presiding officer, who may be the traditional leader, usually then makes a determinative order that reflects the views of the majority of the community members. 95

Since most contracts in African customary law involve the interests of an entire family or tribe, remedies for breach of contract are usually aimed at preserving the social ties between the families of the parties involved, in addition to ensuring the proper fulfilment of the contract. On a more general note, Bennett argues that the dealings of customary courts tend to be reconciliatory. ${ }^{66}$ This contrasts with the formal courts' method of dispute resolution, which is more adversarial, usually with a clear winner and loser.97 A further difference relates to the fact that in the formal court system, the 'male elders' are substituted for relatively younger judicial officers, whose number may include female officers. The net result of these differences is that most

\footnotetext{
${ }^{86}$ Himonga \& Nhlapo (note 4 above) 256; Bennett (note 4 above) 142.

${ }^{87}$ Himonga \& Nhlapo (note 4 above) 256; Bennett (note 4 above) 142.

${ }^{88}$ Himonga \& Nhlapo (note 4 above) 259-260; Bennett (note 4 above) 143-145.

${ }^{89}$ Section 12(4) Black Administration Act 38 of 1927. Himonga \& Nhlapo (note 4 above) 256. Bennett (note 4 above) 147 ,

${ }^{90}$ Bekker \& Rautenbach (note 10 above) 242. See, however, HWO Okoth-Ogendo 'The nature of land rights under indigenous law in Africa' in A Classens \& B Cousins Land, Power \& Custom (2008) 95, 96-97 who argues that description of African customary law as 'informal' was one of a number of 'juridical fallacies' regarding African customary law.

${ }^{91}$ Himonga \& Nhlapo (note 4 above) 257.

92 Bennett (note 4 above) 166.

${ }^{93}$ Himonga \& Nhlapo (note 4 above) 257. Bennett (note 4 above) 166.

${ }^{94}$ Bennett (note 4 above) 166.

${ }^{95}$ Himonga \& Nhlapo (note 4 above) 257. Bennett (note 4 above) 167.

${ }^{96}$ TW Bennett 'Human rights and the African cultural tradition' (1993) Transformation 22.

${ }^{97}$ See also B Goldin \& M Gelfand African Law and Custom in Rhodesia (1975) 245; A Ladley 'Changing the Courts in Zimbabwe: The Customary Law and Primary Courts Act' (1982) 26 J of African Law 103.
} 
customary disputes are resolved within the confines of the families of the parties involved, rather than in the formal courts. The same male elders who were consulted during the formation of the contract are usually asked to play a role in the negotiations toward the peaceful and conciliatory resolution of any contractual disputes. Kariuki argues that this method of African dispute resolution exists even in societies which do not formally recognise the 'institution' of male elders and that this system continues to operate outside the influence of the State. 98

In sum, traditional courts operate in a highly relational community context, where disputes are viewed as embedded within the context of broader society. This leads to a process of dispute resolution more focused on inter-personal relationships than clear legal rights. 99 The result is that customary contracting cannot be viewed as divorced from the relationship between the parties and their respective families, pointing toward an intersection between relational contract theory and traditional customary contracting and concomitant dispute resolution processes. An important unanswered question, however, is as to whether the account thus far in part 3.2 and 3.3 has represented 'official' or 'living' customary law, since most of the sources drawn on above are written library sources, particularly the works of African customary law scholars, legislation, and judicial precedent. The reader may further ask whether the above representation holds true in the heterogeneous and (sometimes) transient populations of South Africa's urban townships. In the following part 4 we move to this latter context, but we will introduce a new economic element into our own narrative, setting out the concept of a 'popular economy'.

\section{African commercial contracting in the popular economy}

The South African economy is a market-based one, with freedom of economic activity enshrined as a fundamental right in the Constitution. ${ }^{100}$ This capitalist feature is balanced with other entrenched socio-economic rights, however, and is backed up by a system of government-sponsored social assistance. ${ }^{101}$ While public services particularly healthcare, education, and policing - are frequently criticised, the social grants paid on a monthly basis to a large number of recipients provide a source of welfare and basic income to many South Africans who are not in formal employment. The grants in question represent a meagre, yet steady, income stream, but are not universally available and need to be supplemented by South Africa's poor and unemployed in order to survive. ${ }^{102}$ These gaps left in the economic framework, provide

\footnotetext{
98 F Kariuki 'Conflict Resolution by Elders in Africa: Successes, Challenges and Opportunities' available at: <https://www.ciarb.org/docs/default-source/centenarydocs/speaker-assets/francis-kariuki.pdf?sfvrsn1/40>1. See generally: JL Comaroff \& S Roberts Rules and Processes: The Cultural Logic of Dispute in an African Context (1981) at chapter 1.

${ }^{99}$ Bennett (note 6 above) 138, 138-141.

${ }^{100}$ Section 22 of the Constitution of the Republic of South Africa, 1996.

${ }^{101}$ Social Assistance Act 13 of 2004. See generally: M Olivier 'Social Security: Framework' in WA Joubert (ed) The Law of South Africa Vol 13(2) 2 ed (2012).

102 There are various categories of social grant available, including 'Grants for Older Persons' and 'Child Support Grants'. The relevant government website is: <http://www.sassa.gov.za/index. php/social-grants>. To give ballpark figures: the 2017 budget speech announced that the grant for older persons (state pension) would be increased to R1 600 per month that year.
} 
the context for the so-called 'popular economy', a notional space where traditional African culture and contemporary (South African) existence intersect.103

In the social sciences, a distinction is sometimes drawn between the 'formal' and the 'informal' sectors. ${ }^{104}$ In the South African context, this could be used to distinguish between those in salaried employment, and those who make a living based on their entrepreneurial talents, outside of the mainstream economy reflected in tax records. ${ }^{105}$ Scholars working on the popular economy have shown the formal/informal dichotomy to be misleading, however. ${ }^{106}$ This is because 'formal sector' wages may be employed as capital for 'informal sector' entrepreneurship, or as a means of support (through remittances) for third parties who are engaged in 'informal' economic activities. ${ }^{107}$ The term 'popular economy' thus captures the broader social context in which South Africans live and operate, particularly at the fringes of the mainstream economy.

The popular economy is a common context for empirical studies by economic anthropologists or sociologists, but it is not often considered by doctrinal lawyers; certainly not by mainstream contract lawyers. We believe that it is a good setting in which to base our discussion of the living customary law of commercial contracts. This is because this social context exists largely beyond the reach of the common law, with business norms hence being located in cultural practices. To the extent that this milieu is 'African', although probably neither homogeneous nor drawing from only one ethnicity, we are able to observe a stronger role for African cultural contracting practices. Of course, this is not to say that many who live by the tenets of African customary law in some aspects of their lives are not engaged in mainstream economic activities. Clearly there is a black middle class, many of whom engage in blue chip commercial contracting as both principals and agents. Our argument is rather that if we are looking for the living customary law of commercial contracting, which we suggest is possibly different from the mainstream common law of contract and (as of yet) is largely un-amalgamated with this version, a good place to begin is in the contract practices which are occurring amongst the African population outside of the mainstream economy. This approach assumes a concept of contract law based in deep legal pluralism.

Our inquiry aims to answer this question: if a businessperson contracts in one of the South Africa's large townships, what is the governing legal system? The law on the books (positivist/centralist) answer would probably refer to the mainstream contract law, to be applied through the mainstream court system (including the Small Claims Court), or through recognised alternative dispute resolution tribunals (such as industry Ombuds or

\footnotetext{
${ }^{103}$ For a clear defence of the popular economy concept, see: E Hull \& D James 'Introduction: Popular Economies in South Africa' (2012) 82 Africa 1. For further context see: J Seekings 'Taking Disadvantage Seriously: the 'Underclass' in Post-Apartheid South Africa' (2014) 84 Africa 135.

${ }^{104}$ Keith Hart is usually credited with having first defined this dichotomy in the 1970s, see: K Hart 'Informal Income Opportunities and Urban Employment in Ghana' (1973) 11 Journal of Modern African Studies 61.

105 See the sources cited in note 103 above.

${ }^{106}$ Hull \& James note 103 above at 7-10. See further: the other articles in this special edition of Africa (2012); Seekings \& Nattrass (note 3 above).

${ }^{107}$ Hull \& James note 103 above at $7-10$.
} 
the National Consumer Tribunal). A law in action response might acknowledge in contrast, however, that much of this popular economy contract practice occurs outside of the formal contract regime, in the sense that the positive law may not be known to the participants; legal representation may be unaffordable or undesired; and the system of courts viewed with suspicion or as too far removed from the everyday realities of contracting parties. ${ }^{108}$ This type of response is supported by several studies by social scientists working in South Africa, ${ }^{109}$ as well the anecdotal (lived) experience of the two authors of this paper. In what follows, a basic literature review will be given of the sources which led to our thesis; as well as a brief introduction to the world-wide discourse on non-contractual relations and private ordering, which are key features of relational contracting and at the heart of our central argument: namely, that the living customary law of contracting is relational in nature.

\subsection{The popular economy and contracting}

Economics as a field deals with the question as to how scarce resources are allocated in society. ${ }^{110}$ Anthropology is the study of culture, and sociology the study of social organisation. ${ }^{111}$ Contract law, by contrast deals with the rules and principles which govern (particularly economic) transactions. 'Contract practice', in our conceptualisation is a broader area, dealing not only with governing rules and principles, but also with aspects of economics (underlying motivations: wants and needs with regard to resources), as well as anthropology and sociology (what is the business culture in a given group and how is it organised to facilitate commerce?). ${ }^{112}$ Using a plural conception of 'contract law', whereby norms are generated not only by central government, but also by the practice of communities, we intend to link the living customary law of contract to the descriptions of contract practice by economists, anthropologists, and sociologists. This conceptual progression is the background to how we will derive our core hypotheses about the living customary law of contracting from the contract practice described in accounts of the popular economy.

Several empirical studies have dealt with issues related to contracting like: informal credit, ${ }^{113}$ informal risk management, ${ }^{114}$ informal trade, ${ }^{115}$ banks, ${ }^{116}$ stokvels, ${ }^{117}$

\footnotetext{
${ }^{108}$ See part 4.2 below. Support for this type of inter-disciplinary study of law, which rejects the existing formal discourse as incomplete and distorted could find a theoretical grounding in the post-structuralist analysis of law as a 'general', rather than a 'restricted' jurisprudence. C Douzinas \& A Geary Critical Jurisprudence: The Political Philosophy of Justice (2005) argue at 17 that a '[General jurisprudence] accepts the importance that the context has in understanding the law, but places context within the legal text and reads legal texts and legal history as aspects of social being in which other expressions of sociality, like politics, economics or ethics, will be reflected.'

${ }^{109}$ See for example the sources listed in notes $113-118$ below.

${ }^{110}$ MQ Patton Qualitative Research \& Evaluation Methods 3ed (2002) 216.

${ }^{111}$ Ibid.

112 This broader, socially embedded understanding of contracting is core to the themes in the literature related to relational contract theory, such as 'contractual relations'; 'non-use of contract'; and 'private ordering'. For a discussion of this theory, see part 4(c) below.

${ }^{113}$ See for example: D James 'Money-Go-Round: Personal Economies of Wealth, Aspiration and Indebtedness' (2012) 82 Africa 20; MP Mashigo 'Social Structures and Financial Service Delivery to Poor Households in South Africa' (2012) 47 Journal of Public Administration 330; D Porteous \& E Hazelhurst Banking on Change: Democratising Finance in South Africa, 1994-2004 and Beyond (2004) chapters 4-6; CR Cross 'Informal Credit - Or, How Does a Rural Community Capitalize Itself?' paper presented at the 17th annual congress for the association of sociology in Southern Africa held at the University of Natal, Durban 1986.
} 
and burial societies. ${ }^{118}$ All of the above studies were situated in South Africa amongst the indigenous African population, although similar studies have been done in other African countries. ${ }^{119}$ Different normative points of view are advanced in this material and different types of questions are asked, using qualitative and quantitative research methodologies. What emerges strongly from all these accounts, however, is that there is vibrant commercial activity going on in the popular economy, underpinned by economic transactions and hence 'contract practice'. ${ }^{20}$ The picture painted in such sources is different to the types of transaction mentioned in the leading works on African customary law, although the community-orientated nature of most of the transactions suggests a continuity of contexts. ${ }^{121}$ A tentative view which we venture is that the literature on the popular economy presents primary sources to be used as evidence in the updating of the traditional accounts of African customary contracting: rather than a pre-commercial vision of society, where contracts related mostly to marriage, co-operative labour, or arrangements for the care of livestock; ${ }^{122}$ the popular economy discourse presents a modern, urbanised population, operating in a monetised economy and interacting on various levels with the formal sector economy and law. The appeal of this alternative picture of popular economy contracting is that it is strongly commercial and fills the gaps in the representations offered by more traditional accounts.

For us, this is where the living customary law of commercial contracts is to be found - an empirical study needs to be done which asks questions of a different nature to the concerns of economics, anthropology, and sociology. We need to know how law operates in this sphere. The evidence presented by these empirical studies is incomplete for the purposes of a proper account of contract law, since only contract practice is represented. However, based on popular economy accounts, certain key

\footnotetext{
${ }^{114}$ E B€ahre 'The Janus Face of Insurance in South Africa: From Costs to Risk, From Networks to Bureaucracies' (2012) 82 Africa 150; LG Mpedi \& D Millard, 'Bridging the gap: the role of micro-insurance in a comprehensive socialprotection system in South Africa' (2010) 31 Obiter 497; A Hutchison 'A Customary Insurance Law?' (2017) 29 SA Merc LJ 17 (forthcoming).

115 The Socio-Economic Rights Institute (SERI - an independent South African NGO) has made this one of their special projects, see the publications on their website, for example: D Webster 'The End of the Street?' Informal Traders' Experiences of Rights and Regulations in Inner City Johannesburg' (2015) available <http://www.serisa.org/images/Seri_informal_traders_report_FINAL_FOR_SIGN_OFF_2.pdf >.

${ }^{116}$ E Hull 'Banking in the Bush: Waiting for Credit in South Africa's Rural Economy' (2012) 82 Africa 168; GA Jones \& A Dallimore 'Whither Participatory Banking? Experiences with Village Banks in South Africa' (2009) European J of Development Research 344; Porteous \& Hazelhurst (note 113 above); P Mashigo \& H Kubir 'Village Banks: A Financial Strategy for Developing the South African Poor Households' (2016) 11 Int J on Banks and Bank Systems 8.

${ }^{117}$ For South Africa see: G Verhoef 'Informal Financial Service Institutions for Survival: African Women and Stokvels in Urban South Africa, 1930-1998' (2001) 2 Enterprise \& Society 259; D James Money from Nothing: Indebtedness and Aspiration in South Africa (2015) 118-146; WG Schultze 'The Origin and Legal Nature of the Stokvel' (Parts 1\&2) (1997) 9 SA Merc LJ 18; 153; MP Mashigo \& C Schoeman 'Stokvels as an Instrument and Channel to Extend Credit to Poor Households in South Africa' (2012) 5 J1 of Economic and Financial Services 49. There is also an international literature, see seminally: S Ardener 'The Comparative Study of Rotating Credit Associations' (1964) 94 J of the Royal Anthropological Institute 201.

${ }^{118}$ RJ Thomson \& DB Posel 'The Management of Risk by Burial Societies in South Africa' (2002) 2 SA Actuarial J 83; Verhoef (note 117 above) 266-269; Schultze (note 117 above) 27-29.

${ }^{119}$ CM Dickerson 'Promises of Future Performance and Informal Sector Transfers of Personal Property: The Example of Anglophone Cameroon' (2011) Acta Juridica 285; M Fafchamps 'The Enforcement of Commercial Contracts in Ghana' (1996) 24 World Development 427.

${ }^{120}$ See for example the sources listed in footnotes 113-118 above.

121 The examples given by Himonga \& Nhlapo (note 4 above) in chapter 10 relate almost entirely to a familial context, or to contractual relations between members of a community.

${ }^{122}$ Compare: Himonga \& Nhlapo (note 4 above) chapter 10; Bekker (note 27 above); Rautenbach \& Bekker (note 10 above) chapter 7.
} 
features emerge about contracting in this sector. For the present authors, these answers can be distilled into a number of broad propositions:

i.Credit is usually extended to relatives, friends, or other known associates. Credit is seldom extended to strangers - that is the role of conventional banks and microlenders. The reason for this feature is the high degree of knowledge about a contracting counter-party, which induces trust and reliance. The problems of adverse selection and moral hazard are reduced by this factor, and knowledge-based trust serves as collateral. ${ }^{123}$

ii.Executory contracts are thus known to the popular economy: risk is managed as above through symmetrical knowledge structures. Peer pressure also plays a role, given the ability to do reputational harm to a contracting party through negative gossip..$^{124}$

iii.'Ubuntu', or a communitarian conception of fair dealing, is to be found in the popular economy, and a lack of this quality is sometimes advanced as a criticism of formal sector contracting parties, such as banks and other micro-lenders. ${ }^{125}$

iv.But, promises are to be kept, in the sense that obligations are viewed as binding and parties as autonomous. ${ }^{126}$

v.Dispute resolution between members of the community is capable of being resolved through non-legal means. Disputes with formal sector partners, particularly financial institutions, can present a problem due to the dictates of the positive law and legal procedure. ${ }^{127}$

The emergent picture is thus that contracting in the popular economy is communitycentred and -centric. A community-based form of contracting means that transactions probably occur between repeat players, who are known to one another. This makes it probable that there is a strong relational element to contracting in the popular economy, at least where contracting is between community members. Before defending this theoretical claim, however, we will, as in the previous part 3, explore dispute resolution, this time in the South African urban township milieu.

\subsection{Dispute resolution in South Africa's urban townships}

An urban format of African customary law is applied through informal dispute resolution mechanisms which are influenced by African customary law in order to

\footnotetext{
123 James (note 117 above) 124; Mashigo \& Kubir (note 116 above) 11; MP Mashigo Extending Credit to the Lowincome and Poor Households in South Africa: A System of Principles unpublished PhD thesis (University of Johannesburg, 2007) chapter 4; Verhoef (note 117 above) 272-278.

124 Thomson \& Posel (note 118 above) 109-111; Mashigo (note 123 above) chapter 4.

${ }^{125}$ For use of the term 'ubuntu' in this context, see: Verhoef (note 117 above) 273. On the relationship between the 'community' and formal sector parties, such as banks, see the general narrative in Jones \& Dallimore (note 116 above) (although the tone is sceptical here). See, however, the sceptical view of Erik B€ahre Money and Violence (2007) at 133-139, who cautions that the concept of 'ubuntu' is not comfortable in an anthropological account of the popular economy.

126 This is fundamental to an analysis of contracting in any community. In this article we suggest two alternative means of enforcement (beyond formal sector courts), namely: (1) through relational means as in the text attached to note 144 below; or (2) through dispute resolution platforms, as discussed in part 3.3 above and part 4.2 below.

${ }^{127} \mathrm{~B} €$ ahre (note 114 above) discusses this key factor at 160-163. In a similar context, see: PM Nienaber \& J Preiss 'Funeral insurance: A perception from the office of the ombudsman for long-term insurance' (2006) 18 SA Merc LJ 291. On township dispute resolution platforms, see the following part 4(b).
} 
manage conflict and maintain peace in the townships. ${ }^{128}$ The courts apply neither traditional (read: 'textbook') African customary law nor common law, but utilise a mixture of the two, with a strong basis in African customary law norms. ${ }^{129}$ The relevant dispute resolution bodies are the Street Committees or Section Committees who perform the function of urban customary courts. ${ }^{130}$ These committees form the second tier of informal courts in the townships after the family court and have jurisdiction over a number of streets (a variety of methods is used to determine geographical boundaries). In other communities, Street Committees report to Executive Committees or Ward Committees; thereafter, the matter goes to the police. ${ }^{131}$ Such committees meet either in community public places or in members' homes, hearing civil cases which mainly relate to disputes between community members. They also liaise with formal authorities such as the police and municipalities on behalf of the community.

Burman and Scherf argue that these dispute resolution structures in the townships are based on the informal courts of the rural areas. ${ }^{132}$ The township versions resemble customary courts in that they are informal and hence less intimidating than the formal courts: no legal representation is required; no fees are involved for a case to be heard; proceedings are held in familiar surroundings; tribunals apply the basic communitarian principles which people are used to; and proceedings commence at the family level and escalate through various platforms to a formal court, as per traditional customary dispute resolution. ${ }^{133}$ These township structures hence provide great utility to inhabitants, since due to the residential layout of these communities, formal governance and policing achieve only a low level of penetration. ${ }^{134}$ In addition, community members tend to have a lack of confidence in the formal judicial structures, compounding such utility. 135 Great emphasis is usually placed on mediation in order to reconcile parties, with the ultimate goal being settlement. In practice, it is often the case that when parties report a dispute to the police they are advised to first approach a community dispute resolution platform..$^{136}$

Although the account above is brief, one can see the interplay between formal structures (such as police and governance services) and these informal dispute resolution tribunals in South Africa's popular economy. The existence of these

\footnotetext{
${ }^{128}$ Bennett (note 42 above) 91. See further: J Seekings 'The revival of 'people's courts': Informal Justice in Transitional South Africa' in G Moss \& I Obery (eds) South African Review 6 (1992) 186; S Burman \& W Sch€arf 'People's justice: street committees and people's courts in a South African city' (1990) 24 Law and Society Rev 693; BDD Radipati 'Informal dispute resolution in South Africa: A comparative and jurisprudential study' unpublished LLM dissertation (University of the Witwatersrand, 1993).

${ }^{129}$ Bennett (note 42 above) 91.

${ }^{130}$ Burman \& Sch€arf (note 128 above) 706.

${ }^{131}$ Ibid 706-707.

132 Ibid 693.

${ }^{133}$ Bekker \& Rautenbach (note 10 above) 246. Bennett (note 4 above) 155, 158.

${ }^{134}$ Bekker \& Rautenbach (note 10 above) 246.

135 Ibid at 246-247.

${ }^{136}$ In this regard, see also W Sch€arf 'Policy options on community justice' in W Sch€arf \& D Nina (eds) The other law. Non state ordering in South Africa (2001) 39; C Shearing 'Transforming security: a South African experiment' in H Strang \& J Braithwaite (eds) Restorative justice and civil society (2001) 14; J Seekings 'The changing face of urban civic organization' (2011) 75 Transformation 140; J Froestad \& C Shearing Security governance, policing, and local capacity (2012).
} 
popular economy platforms also demonstrates the scope for private ordering to govern contractual disputes in this sphere. Hence, super-imposed on ordinary party-toparty contractual relations and resultant inter-personal ordering, there is an additional layer of private ordering, through community structures. For us, this second layer of ordering reinforces our argument that contracting in the popular economy is relational, since it is not just the parties' own relationship which needs to be preserved, but the harmony of the greater community as a whole. In the following section we will build on the findings reached thus far in part 4 to construct our own theory of African customary commercial contracting in the popular economy.

\subsection{Legal pluralism and relational contract theory in the popular economy}

Moving from a review of the empirical literature to the literature on socio-legal theory, we return to our discussion of the overlap between legal pluralism and relational contract theory, as alluded to above. The genesis of relational contract theory was in the United States, although it has adherents in other countries as well: particularly the United Kingdom, but also in South Africa. ${ }^{137}$ A very clear articulation of the general argument put forward by this movement could be briefly set out with reference to the work of Hugh Collins. ${ }^{138}$ Using Collins's analysis, we will argue that a contractual relation (in the sense of an ongoing nexus between two or more parties, underpinning a particular transaction between them) can be viewed as existing on three planes: First, there are terms of the agreement itself, whether written or oral. Second, there are the underlying economic considerations motivating both parties such as, how does the conclusion of this transaction increase each party's utility? Finally, there is the human element of the transaction: the inter-personal relationship between the parties. This three-dimensional ${ }^{139}$ analysis allows for a broader perspective on the contractual relation. In particular, it allows for the influence of extraneous circumstances of the non-legal variety on the contractual relationship between the parties. This, we suggest, is a human-centred approach to contracting, which fits well into a community setting with repeat players.

The literature on stokvels, burial societies, and other forms of savings and risk management clubs suggests that transactions in this sphere are enforced through relational means; particularly, using the above analysis, the economic and interpersonal planes. This, we suggest, could be partially explained by the literature on 'non-contractual relations'. ${ }^{140}$ This school of thought holds that contract disputes are

\footnotetext{
${ }^{137}$ See the sources cited in note 18 above for the key US and UK materials. For South Africa, see: L Hawthorne 'Relational Contract Theory: Is the Antagonism Directed at Discrete Exchanges and Presentiation Justified?' in G Glover (ed) Essays in Honour of AJ Kerr (2006) 137 and 'The First Traces of Relational Contract Theory - The Implicit Dimension of Co-operation (2007) 19 SA Merc LJ 234; T Cohen 'The Relational Contract of Employment' (2012)Acta Juridica 84-101; A Hutchison 'Relational Theory, Context and Commercial Common Sense: Views on Contract Interpretation and Adjudication' (2017) 134 SALJ 296.

${ }^{138} \mathrm{H}$ Collins (note 18 above); H Collins 'The Contract of Employment in 3D' in D Campbell, L Mulcahy \& S Wheeler (eds) Changing Concepts of Contract: Essays in Honour of Ian Macneil (2016) 65.

139 The 'three dimensional' descriptor is borrowed from Collins (note 138 above).

${ }^{140}$ Macaulay (note 13 above) is the seminal text here. See further: D Campbell 'What do we mean by the non-use of contract?' in J Braucher, J Kidwell \& WC Whitford (eds) Revisiting the Contracts Scholarship of Stewart Macaulay (2013) 159, 164.
} 
largely resolved by negotiation between the parties: this not only preserves the relationship (and in a community setting, a measure of social harmony), but also avoids transactions costs, particularly in the form of time and money, which are necessitated by a recourse to the formal law or formal legal dispute resolution mechanisms. ${ }^{141}$ A distrust of lawyers and the utility which they add to a contractual relation can be found in several international studies of businessmen. ${ }^{142}$ Similar evidence is also to be found in the sources on the popular economy, along with the obvious point that recourse to the formal law is beyond the financial means of many popular economy participants, even if they wanted to go this route. ${ }^{143}$

If we move beyond formal sector adjudicative platforms to alternative means of contract enforcement based on community relations, what form of coercion is left to the parties to a customary commercial contract? The answer is non-legal sanctions: ${ }^{144}$ a refusal to do repeat business (an economic sanction) can shut off a vital avenue of supply, whether of goods, services, or credit. Similarly, adverse comment and social peer pressure (inter-personal sanctions) can motivate contractual compliance in a situation where parties are members of a community where these factors matter. Opportunism, in the sense of selfish exploitation of the vulnerabilities of others under a given contractual matrix, is of course a universal human condition, and explains some of the reported cases of default and fraud. In a normative sense, however, a lack of perfect success for the community-enforcement model does not negate it as a system of 'private ordering', by which term we signify that the transactional matrix operates largely without recourse to central law enforcement, through the actions and interventions of players in the market.145 In our view, such a system, displaying a system of normative practices allowing for private ordering could also be described as deep legal pluralism; if one accepts the premise of this legal theory that 'law' originates in the practices of a given community, provided these are viewed as binding by that community. Then, assume that this community, which practises private ordering in their contractual relations with each other, also adheres to traditional African customary law normative practices, such as the payment of lobola when getting married. On this basis, a strong argument could be made that system of contractual private ordering constituted the living customary law of commercial

\footnotetext{
${ }^{141}$ See Macaulay (note 18 above). For an account of transaction cost economics linking this concept to relational theory, see: OE Williamson The Economic Institutions of Capitalism (1985).

${ }^{142}$ In addition to Macaulay (note 18 above), see: S Deakin, C Lane \& F Wilkinson 'Contract Law, Trust Relations, and Incentives for Co-operation: A Comparative Study' in S Deakin \& J Michie (eds) Contracts, Co-operation, and Competition (1997) 105; Hugh Beale \& Tony Dugdale 'Contracts between Businessmen: Planning and the Use of Contractual Remedies' (1975) 2 British Journal of Law and Society 45.

${ }^{143}$ See the discussion in part 4.1-4.2 above.

${ }^{144}$ See for example: David Charny ‘Nonlegal Sanctions in Commercial Relationships' (1990-91) 104 Harvard LR 373; Collins (note 18 above) chapter 5 .

145 For an overview of the 'private ordering' literature, see: BD Richman 'Firms, Courts and Reputation Mechanisms: Towards a Positive Theory of Private Ordering' (2004) 104 Columbia LR 2328. For empirical studies, see: RC Ellickson Order Without Law: How Neighbors Settle Disputes (1991); L Bernstein 'Opting out of the Legal System: Extralegal Contractual Relations in the Diamond Industry' (1992) 21 Journal of Legal Studies 115; L Bernstein 'Merchant Law in a Merchant Court: Rethinking the Code's Search for Immanent Business Norms' (1995-96) 144 University of Pennsylvania LR 1765; L Bernstein 'Private Commercial Law in the Cotton Industry: Creating Cooperation through Rules, Norms and Institutions' (2000-01) 99 Michigan LR 1724. For an African perspective, see: Fafchamps (note 119 above).
} 
contracting, whether applied directly through relations inter partes, or by a more formalised township community platform. While we accept that indigenous black South Africans may live by African customary norms in some aspects of their lives (such as marriage and family relations), but not in others (such as their business dealings), it must be to those who are cultural insiders that a researcher looks when testing for contract practice and a business philosophy which is definitively 'African' and possibly thus distinct from Eurocentric norms. It is in this realm of cultural adherents that a living customary law of commercial contracting must be sought.

\section{The living customary law of commercial contracting: some hypotheses}

To summarise, the argument thus far in this paper raises three central hypotheses:

i.Contracting in the popular economy is highly relational, resting on what are described in the world literature as 'non-contractual relations'; 'non-legal sanctions'; and 'private ordering'.

ii.In a given community transacting amongst each other in the South African popular economy, the resultant contractual relations give rise to a normative order which constitutes the living customary law of commercial contracting. This living law of contracting may involve an interplay between indigenous forms of contract practice and formal sector institutions, particularly banks.

iii.This interplay is at the heart of the formal/informal sector intersection which typifies the popular economy, making this the key locus in which to study a modern, urbanised living customary law of commercial contracts. The final answer to the question, 'what is African about contracting in South Africa?' is thus to be found through empirical research in this context.

\section{Conclusion}

All that remains then is for us to tie up the narrative threads left unresolved by our opening discussion in parts 1 and 2 above. This article has suggested some answers to the questions:

i.'What is African about contracting in South Africa?'; and

ii.'What is the role of community in contracting in South Africa's popular economy?'

Our suggested answers to these questions above show that we interpret the literature as suggesting that 'community' remains at the heart of African contracting in the popular economy; and that the same would appear to be true of the traditional discourse. We agree with Gyekye, however, that this is a moderate form of communitarianism, which accepts a role for individualism and private property, but also imposes a measure of social responsibility. Perhaps, using the Constitutional Court's own narrative, one could call this philosophy a state of 'ubuntu'. Is this idealised? Possibly - the empirical sources are replete with examples of the failures of 'community': both through the opportunistic exploitation of counter-parts; and 
through the abuse of African customary structures, such as stokvels. ${ }^{146}$ Opportunism and even fraud are to be found in any system of contracting, however, and their similar presence in African customary contracting should not necessarily derail our theoretical construct.

Another question is how to deal with the plural nature of our legal system and the balance between the equal sources of African customary and common law. For example, having identified a parallel contracting context with its own rules and culture, what is the impact of this to be on the generally applicable common law of contract? The Constitutional Court's argument appears to be that the underlying ubuntu/community ethos of African customary law should inform the common law notion of public policy. ${ }^{147}$ This allows for the protection of weaker parties, which is a good thing, but may have an impact on contractual certainty.148 One possible interpretation of the Constitutional Court's paradigm of argument is that it is aimed at an 'amalgam' of common and African customary law in the future, 149 addressing Chanock's concerns about the segregation of these two sources, and indeed echoing the sentiments of ZK Matthews, expressed as long ago as $1934 .{ }^{150}$ There may be problems here, however, given the lack of epistemological fit between the oral customary law tradition and the written common law one. The Constitutional Court's discourse on ubuntu thus far could also be ascribed (on an alternative basis) simply to the international trend towards the constitutionalisation of contract law to protect weaker parties, which uses open norms such as public policy and good faith to incorporate constitutional values, rather than necessarily drawing these from African customary law per se. This view would open such jurisprudence to the possible criticism of cultural assimilation. Our counterpoint to this argument would be that contracting as a method of facilitating economic exchange is universal to all cultures, resting in large part on economic considerations, rather than only on positive law. Hence conceptual overlap is inevitable and indeed to be encouraged. ${ }^{151}$

Another suggestion as to a possible method of amalgamation could be to recognise yet another parallel contracting regime: in the same way that there are very different regimes of commercial and consumer contract law, there could be a third channel of customary

\footnotetext{
146 A good qualitative example of a source arguing for this position may be found in B€ahre (note 114 above).

${ }^{147}$ See the discussion of public policy in the seminal Barkhuizen (note 12 above), para 51.

148 This conflict is explored in Hutchison (note 34 - 2017) above.

149 Alexkor (note 60 above), para 51. While in Alexkor the Constitutional Court was careful to stress the separate identity of African customary law as a source of law, there is no reason why it should not have an impact on the general South African common law. As past histories of the common law have been at pains to point out, this construct itself has always been a mixture of ideas. The idea of amalgamation is also one possible interpretation of Yacoob J's statement at para 23 of his minority judgment dealing with the common law of contract in Everfresh (note 12 above), as well as the other curial passages cited in that footnote.

${ }^{150}$ ZK Matthews 'Bantu Law and Western Civilisation in South Africa: A Study in the Clash of Cultures' unpublished MA thesis (Yale University, 1934) 354-356. NR Mandela Long Walk To Freedom (1994) 42 describes ZK Matthews, one of his law professors during his LLB studies at Fort Hare and part of an earlier generation of ANC leadership, as 'the very model of the intellectual', who taught 'social anthropology and African law and spoke out bluntly against the [Apartheid] government's social policies.'

${ }^{151}$ In a different context, see the equation drawn between ubuntu, restorative justice and the amende honorable in Dikoko v Mokhatla 2006 (6) SA 235 (CC) in the judgments of Mokgoro J and Sachs J. See further A Mukheibir 'Ubuntu and the Amende Honorable - A Marriage between African Values and Medieval Canon Law' (2007) Obiter 583; GJ van Niekerk 'Amende Honorable and Ubuntu: An Intersection of Ars Boni et Aequi in African and Roman-Dutch Jurisprudence?' (2013) 19 Fundamina 397. A more generalised discussion of social transformation in a multi-cultural context with resultant mingling of cultural identities can be found in HK Bhabha 'Culture's In-Between' in Stuart Hall \& Paul du Gay (eds) Questions of Cultural Identity (1996) 53.
} 
contract law. An appropriate choice of law regime would then have to be worked out, but an ability to choose such a regime would fit nicely with the fundamental premise of contracting as involving the private arrangements of the parties themselves. This second option would preserve the distinct identity of the living customary law of contracting, while allowing for its judicial development. ${ }^{152}$

On status and contract: everywhere there seem to be signs that with the postconstitutional waning of freedom of contract in South Africa, we are reverting from contract to status, echoing Atiyah's claim (with reference to Britain) in 1979.153 Before evaluating a contract, a legal adviser must first ask whether the parties are consumers or commercial entities; or beyond this, whether the context suggests an inequality of bargaining power that may raise constitutional flags. Who the parties to a contract are and the nature of their transaction is highly relevant in the modern South African era. Our literature review above suggests that this is also the case in African customary law, but with the 'status' element possibly being more community-related. Of course, a community-orientated view of contracting can be found in many 'Western' sources as well, the literature on relational contract theory cited above would be a good place to begin such an inquiry. It thus seems fair to argue that in modern South African contracting, whether in the common law or the African customary law context, contracting is all about status. This conclusion allows us to make the claim above that the living customary law of commercial contracting should best be analysed in relational terms. Either as a separate construct, or as part of a future amalgamated 'South African law of contract', customary contract adjudication should be a context sensitive exercise, with the relevant contracting community as the foreground consideration.

Whether the argument in this conclusion, or indeed in this article as a whole, entails a 'decolonisation' of contract law, or a means to address our racialise economic inequality, may be debatable. Indeed, one could well ask whether the judicial development of the law of contract is the best tool for effecting economic redistribution, since its effects are immediate to the parties to a particular dispute. Our intention here is merely to start a discussion about the future of South African contract law and to present a review of what we consider to be the relevant literature on African customary commercial contracting.

\section{Acknowledgements}

The authors would like to thank the following persons for comments on a draft of this article: Tom Bennett, Ada Ordor, Cathi Albertyn, Dale Hutchison and the anonymous reviewers. The views expressed in this article should not (necessarily) be ascribed to our reviewers: all opinions and errors are our own.

\footnotetext{
152 An example of scholarship calling for greater judicial development of African customary law as a separate source of law, is: $\mathrm{S}$ Sibanda \& TB Mosaka 'Bhe v Magistrate, Khayelitsha: A Cultural Conundrum, Fanonian Alienation, and an Elusive Constitutional Oneness' (2015) Acta Juridica 256.

${ }^{153}$ See the discussion of this source in note 16 above.
} 


\section{Disclosure statement}

No potential conflict of interest was reported by the authors.

\section{Funding}

This research is based on work supported in part by the National Research Foundation of South Africa (grant number 10989). Any opinion, finding and conclusion, or recommendation expressed in this material is that of the authors and the NRF does not accept any liability in this regard. 